\title{
PERANCANGAN SISTEM INFORMASI PENGGAJIAN DOSEN BERBASIS WEBSITE DI AMIK AL MA'SOEM JATINANGOR
}

\author{
Sylvia Novitasari \\ STKOM Al Ma'soem \\ novitasarisylvia19@gmail.com \\ Firman Hamdani \\ STKOM Al Ma'soem \\ fhamdani12@gmail.com
}

\section{ABSTRACT}

In payroll data processing, AMIK Al Ma'soem still use semi computerization that is using Microsoft Excel application. Based on the observation of the author there are several weaknesses of the system used so far, namely: not integrated data, risk of duplication, edited and deleted data, reporting takes a long time and no lecturer paycheck.

In the design of this system using a descriptive method approach in collecting data information needed to create a picture of the situation, incident, or the trend that is developing. While for system design isUML (unified Modeling Language). This system is implemented by using PHP web programming language (Hypertext Preprocessor) and MySQL database.

The design of this system is expected to facilitate the users in printing pay slips, printing payroll reports, making assignments, printing report assignments, making absences and lecturers can find information on salary and assignment easily.

Keywords: Information System, Payroll, MySQL.

\section{ABSTRAK}

Dalam pengolahan data penggajian, AMIK Al Ma'soem masih menggunakan semi komputerisasi yaitu menggunakan aplikasi Microsoft Excel. Berdasarkan pengamatan penulis terdapat beberapa kelemahan dari sistem yang digunakan selama ini, yaitu :belum terintegrasinya data, beresiko terjadinya duplikasi, teredit dan terapusnya data, pembuatan laporan membutuhkan waktu yang lama dan belum ada slip gaji Dosen.

Dalam perancangan sistem ini menggunakan pendekatan metode deskriftif dalam pengumpulan data informasi yang dibutuhkan guna membuat gambaran mengenai situasi, kejadian, ataupun kecenderungan yang tengah berkembang. Sedangkan untuk perancangan sistem yaitu menggunakan UML (unified Modeling Language). Sistem ini diimplementasikan dengan menggunakan bahasa pemrograman web PHP (Hypertext Preprocessor) dan database MySQL.

Perancangan sistem ini diharapkan dapat memudahkan para pengguna dalam pencetakan slip gaji, pencetakan laporan gaji, pembuatan penugasan, pencetakan laporan penugasan, pembuatan absen dan dosen dapat mengetahui informasi gaji dan penugasannya dengan mudah.

Kata Kunci : Sistem Informasi, Penggajian, MySQL.

\section{PENDAHULUAN}

\subsection{Latar Belakang Masalah}

AMIK Al Ma'soem yang beralamatkan di Jalan Raya Cipacing No.22 Jatinangor Sumedang, merupakan salah satu perguruan tinggi swasta yang memiliki jumlah dosen 45 orang dengan 333 mahasiswa pada TA 2016/2017. Penggajian dosen AMIK Al Ma'soem di 
dasarkan pada level dan jumlah pertemuan setiap bulannya. Dalam pengolahan data penggajiannya masih semi komputerisasi yaitu masih menggunakan Microsoft Excel dengan formula:

1. Gaji total $=$ gaji persks $*$ sks $*$ jumlah kehadiran + transport

2. Gaji bersih $=$ gaji total - potongan infaq - potongan bank

Sehingga masih terdapat beberapa kendala yang dihadapi. Berdasarkan kelemahan yang ada, penulis mencoba mengagas lagi permasalahkan yang ada dengan mengangkat tema Tugas Akhir dengan judul "Perancangan Sistem Informasi Penggajian Berbasis Website di AMIK Al Ma'soem Jatinangor".

\subsection{Rumusan Masalah}

Pada penyajian Sistem Informasi Penggajian yang digunakan di AMIK Al Ma'soem Jatinangor memiliki kelemahan diantaranya yaitu :

1. Database belum terintegrasi

2. Beresiko terjadinya duplikasi data, teredit dan terapusnya data

3. Proses pembuatan laporan membutuhkan waktu yang lama

4. Belum ada slip gaji dosen

\section{METODOLOGI}

\subsection{Metodologi Penelitian}

Dalampenyusunan Tugas Akhir ini, penulis menggunakan metode deskriptif dalam mendapatkan informasi yang sesuai dengan kebutuhan. Metode deskriptif merupakan metode penelitian yang berusaha menggambarkan dan menginterpretasi objek yang sesuai.Teknik pengumpulan data yang dilakukan penulis meliputi:

1. Observasi

Pengamatan yang dilakukan secara langsung di AMIK Al Ma'soem terpusat pada tata cara pembayaran gaji dosen.

2. Wawancara

Melakukan tanya jawab dengan bagian keuangan dan bagian kurikulum.

3. Studi Pustaka

Pengumpulan data dimaksudkan untuk mendukung penulisan ilmiah dan disajikan paduan yang berkaitan dengan masalah penggajian.

\subsection{Metodologi Pengembangan Sistem}

Dalam perancangan sistem ini menggunakan metode OOAD (Object Oriented Analysis dan Design), dengan aktifitas yang berfokus pada pengembangan model dengan menggunakan Unified ModelLeanguage (UML) sebagai perangkat perancangan sistem, yang terdiri dari :use case diagram, activity diagram dan class diagram.

\section{ANALISA DAN PERANCANGAN SISTEM}

\subsection{Use Case Bisnis}

Use case bisnis terbagi kedalam beberapa use case yaitu sebagai berikut : 


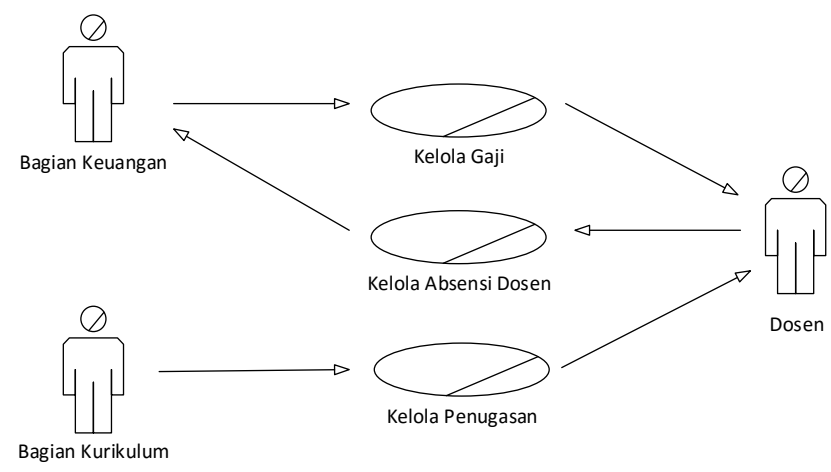

Sumber : Penelitian

Gambar 1 Proses Business Object ModelUser

2. Use Case Bisnis Admin

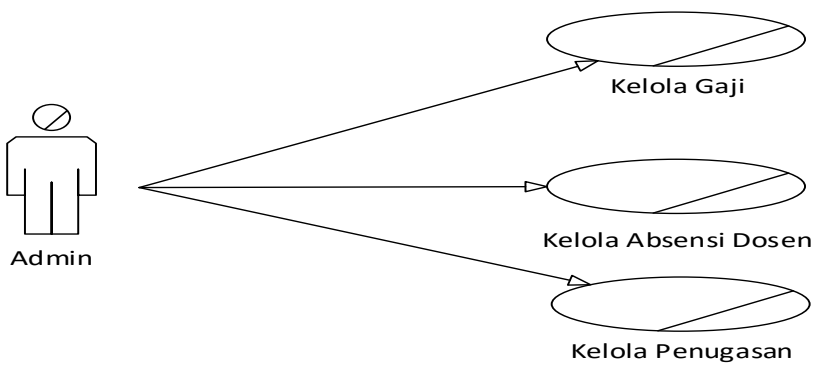

Sumber : Penelitian

Gambar 2Proses Business Object Model Admin

\subsection{Use Case Sistem}

Use case sistem terbagi kedalam beberapa use case yaitu sebagai berikut :

1. Use Case Sistem Bagian Keuangan

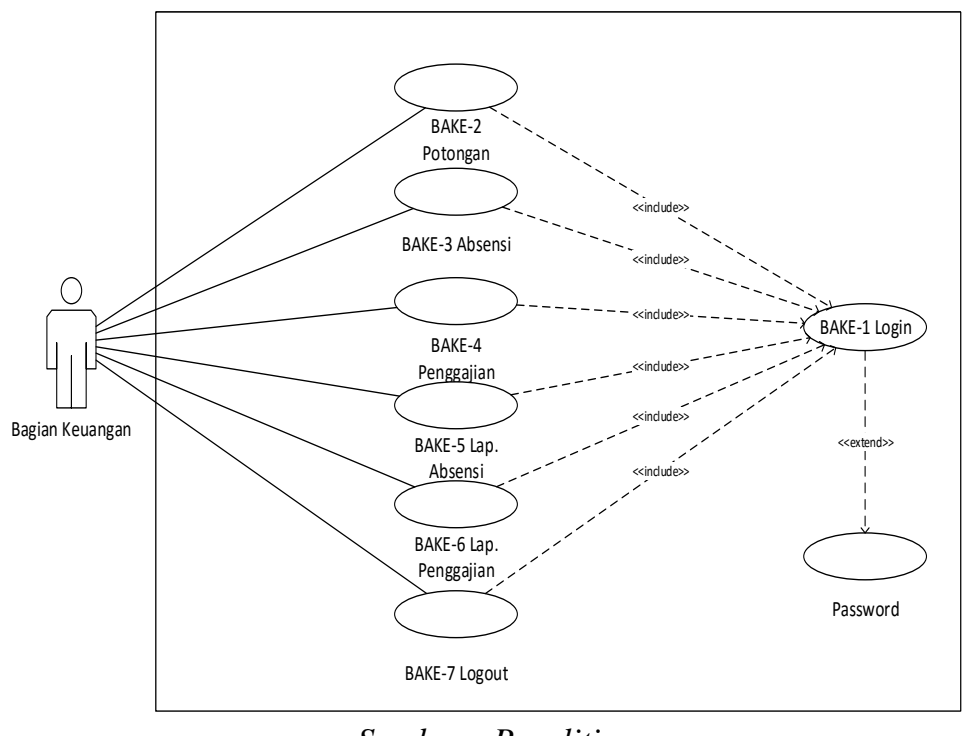

Sumber : Penelitian

Gambar 3 Use Case Diagram Bagian Keuangan

2. Use Case Sistem Bagian Kurikulum 


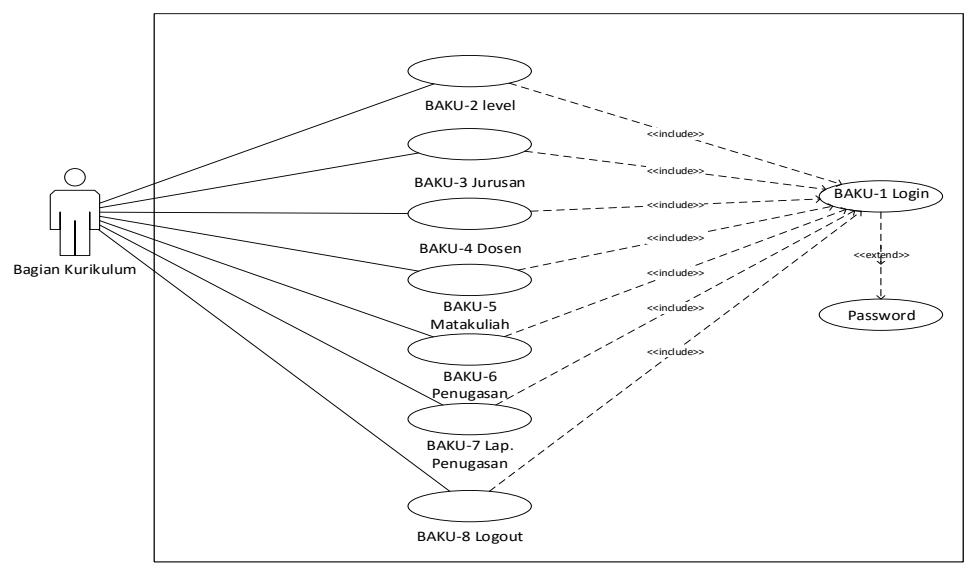

Sumber : Penelitian

Gambar 4 Use Case Diagram Bagian Kurikulum

\section{Use Case Sistem Dosen}

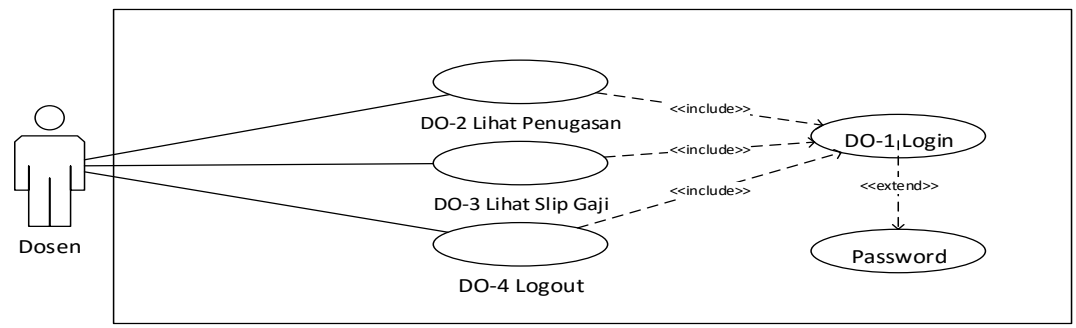

Sumber : Penelitian

Gambar5 Use Case Diagram Dosen

4. Use Case SistemAdmin

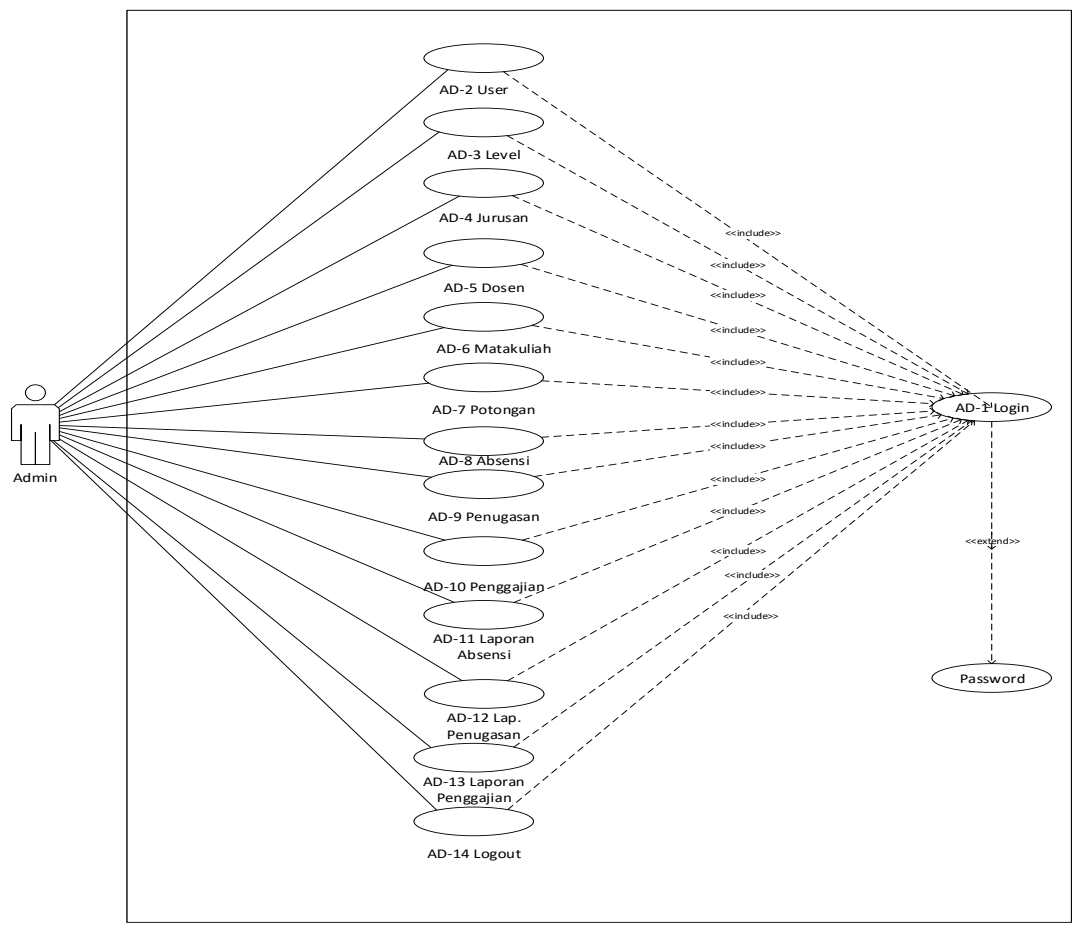

Sumber : Penelitian

Gambar 6 Use Case Diagram Admin

5. Activity Diagram

a. Activity Diagram Bagian Keuangan Login 


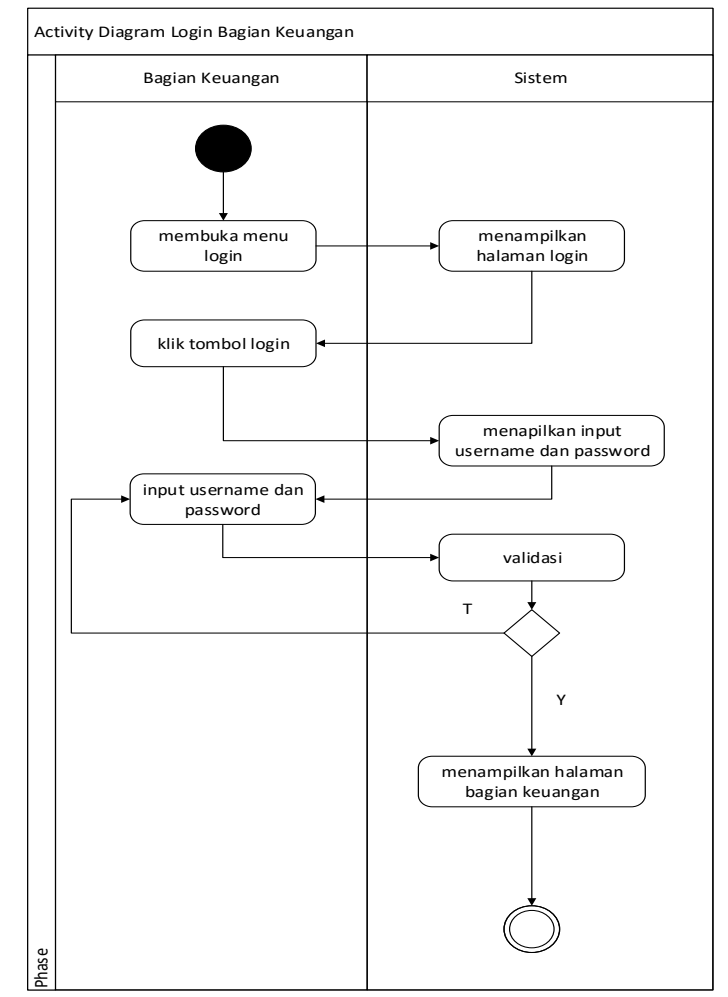

Sumber : Penelitian

Gambar 7 Activity Diagram Bagian Keuangan Login

b. Activity Diagram Bagian Keuangan Absensi

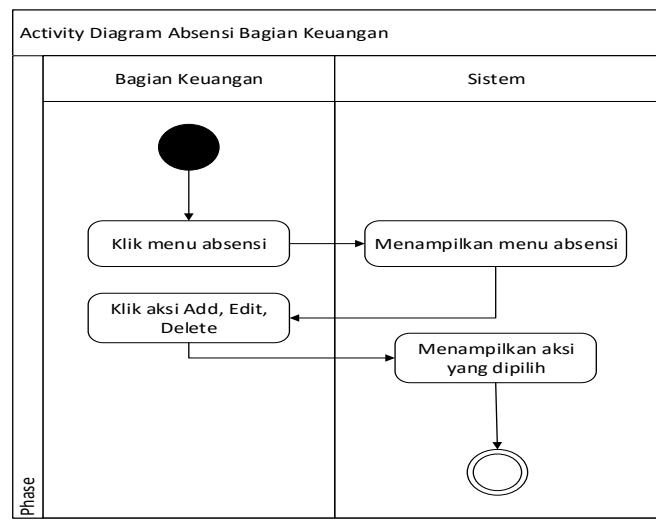

Sumber : Penelitian

Gambar 8 Activity Diagram Bagian Keuangan Absensi

c. Activity Diagram Bagian Keuangan Penggajian 


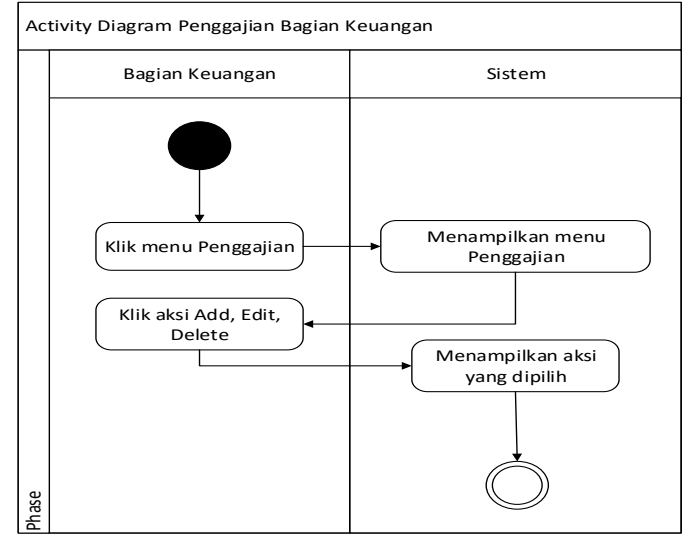

Sumber : Penelitian

Gambar 9 Activity Diagram Bagian Keuangan Penggajian

d. Activity Diagram Bagian Keuangan Potongan

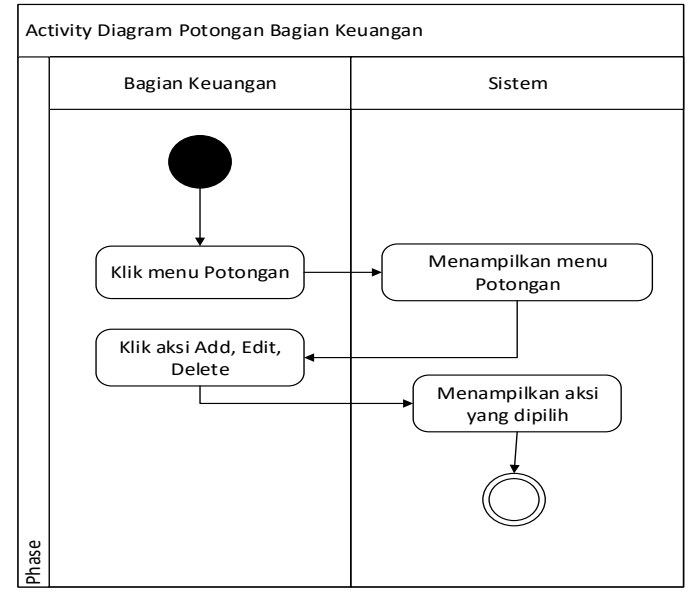

Sumber : Penelitian

Gambar 10 Activity Diagram Bagian Keuangan Potongan

e. Activity Diagram Bagian Keuangan Laporan Absensi

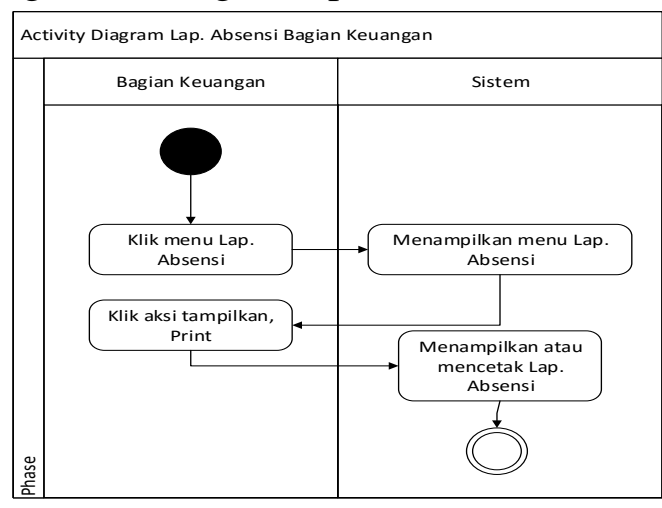

Sumber : Penelitian

Gambar 11 Activity Diagram Bagian Keuangan Laporan Absensi

f. Activity Diagram Bagian Keuangan Laporan Penggajian 


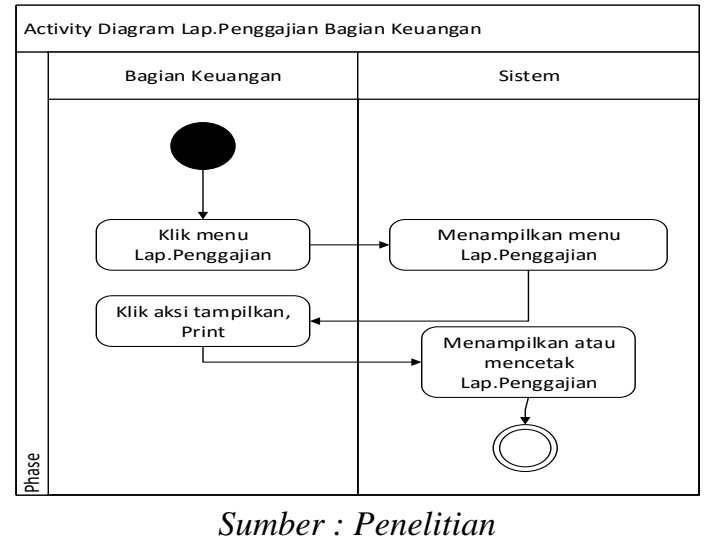

Gambar 12 Activity Diagram Bagian Keuangan Laporan Penggajian

g. Activity Diagram Bagian Keuangan Logout

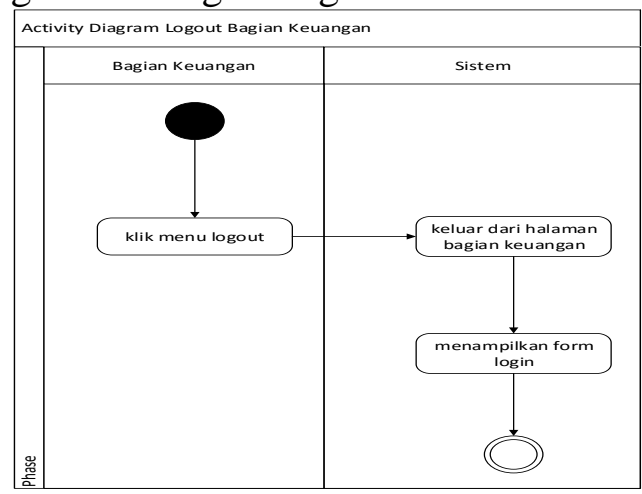

Sumber : Penelitian

Gambar 13 Activity Diagram Bagian Keuangan Logout

h. Activity Diagram Bagian Kurikulum Login

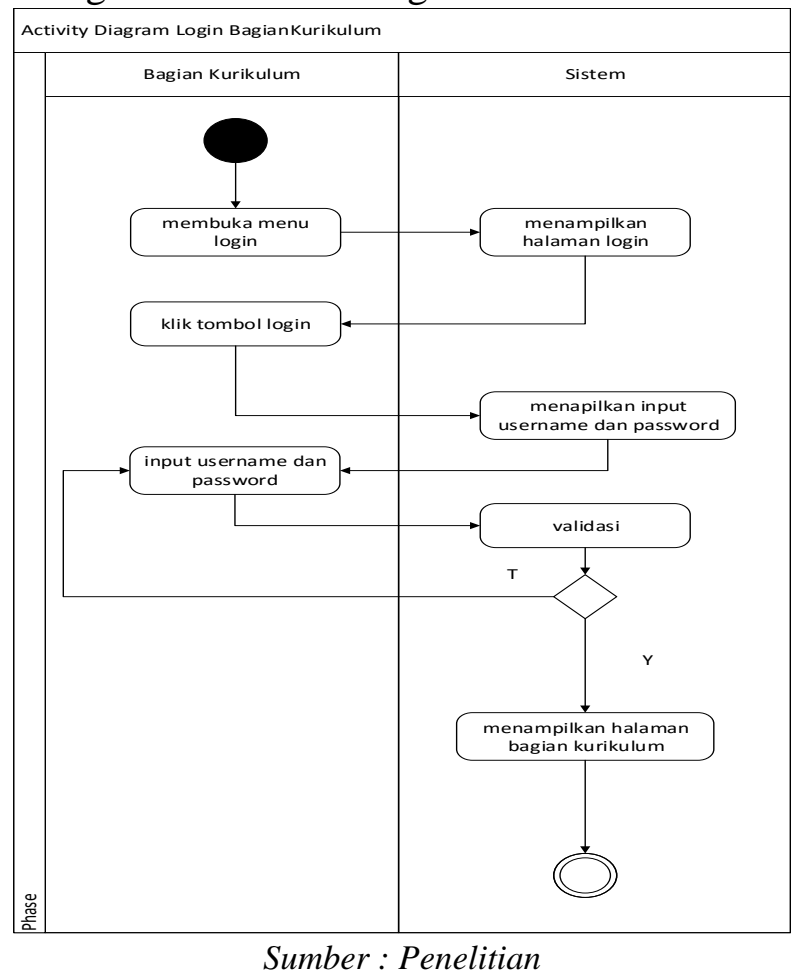

Gambar 14 Activity Diagram Bagian Kurikulum Login

i. Activity Diagram Bagian Kurikulum Jurusan 


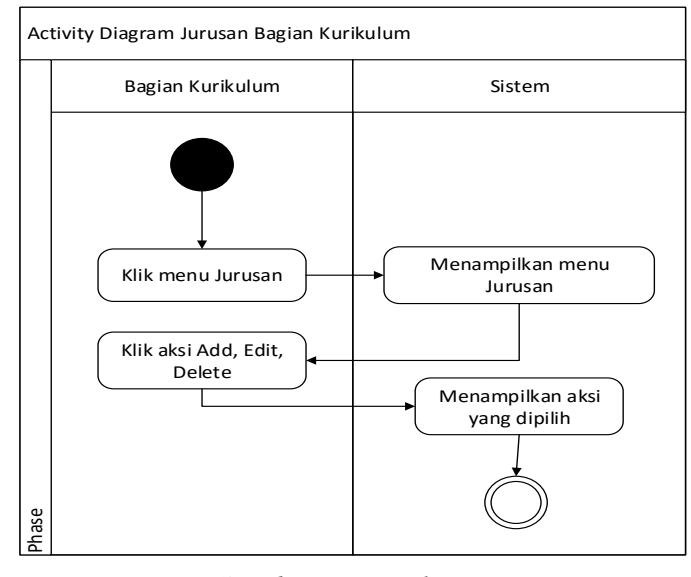

Sumber : Penelitian

Gambar 15 Activity Diagram Bagian Kurikulum Jurusan

j. Activity Diagram Bagian Kurikulum Dosen

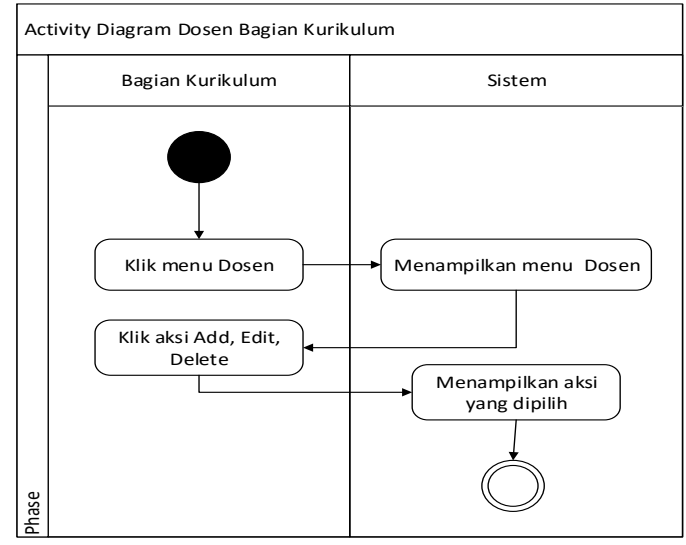

Sumber : Penelitian

Gambar 16 Activity Diagram Bagian Kurikulum Dosen

k. Activity Diagram Bagian Kurikulum Matakuliah

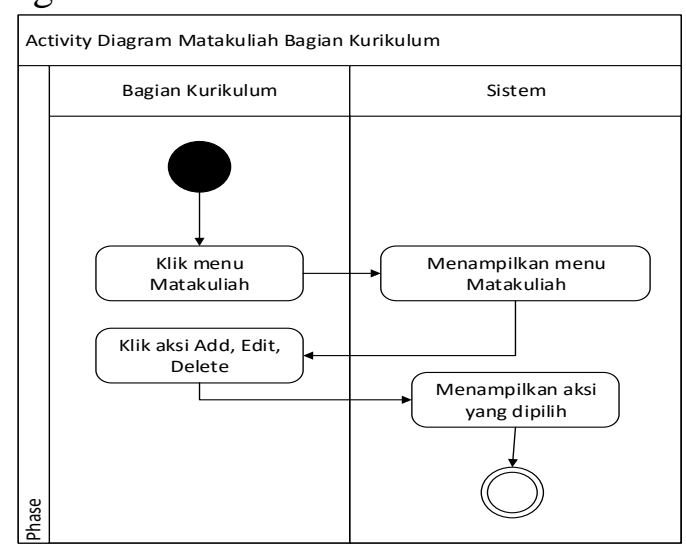

Sumber : Penelitian

Gambar 17 Activity Diagram Bagian Kurikulum Matakuliah

l. Activity Diagram Bagian Kurikulum Level 


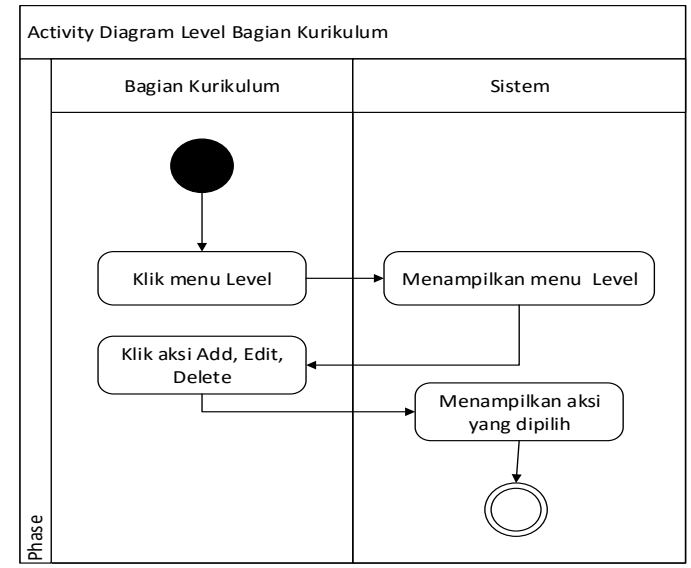

Sumber : Penelitian

Gambar 18 Activity Diagram Bagian Kurikulum Level

m. Activity Diagram Bagian Kurikulum Penugasan

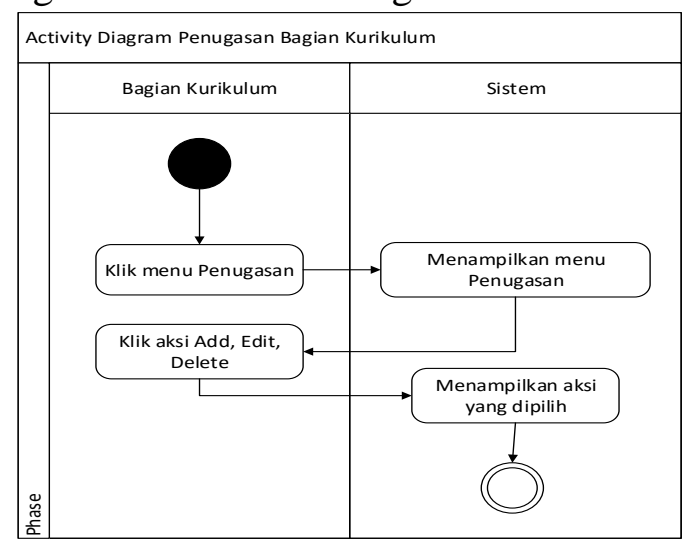

Sumber : Penelitian

Gambar 19 Activity Diagram Bagian Kurikulum Penugasan

n. Activity Diagram Bagian Kurikulum Laporan Penugasan

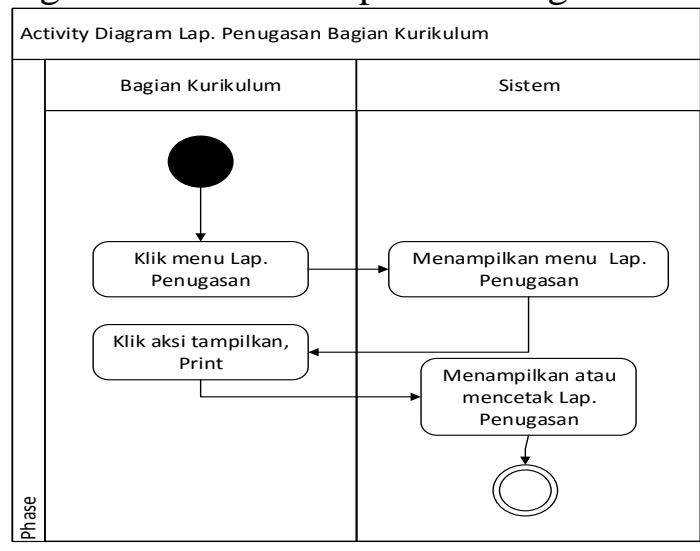

Sumber: Penelitian

Gambar 20 Activity Diagram Bagian Kurikulum Laporan Penugasan

o. Activity Diagram Bagian Kurikulum Logout 


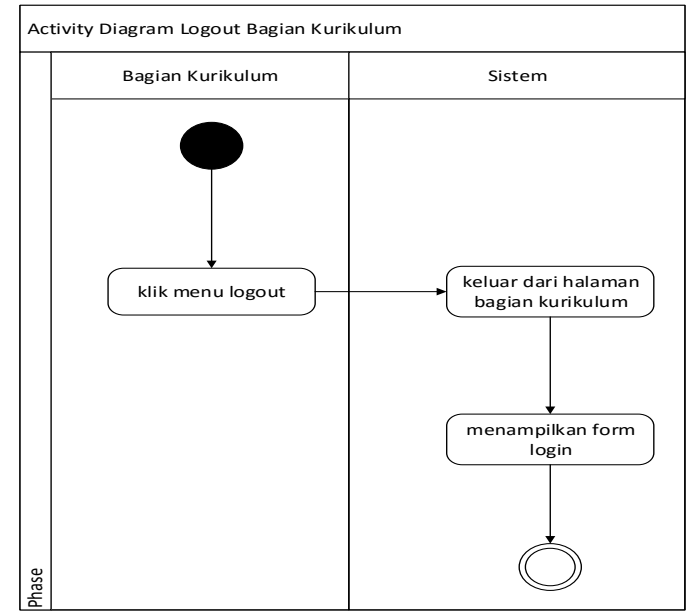

Sumber : Penelitian

Gambar 21 Activity Diagram Bagian Kurikulum Logout

\section{p. Activity Diagram Dosen Login}

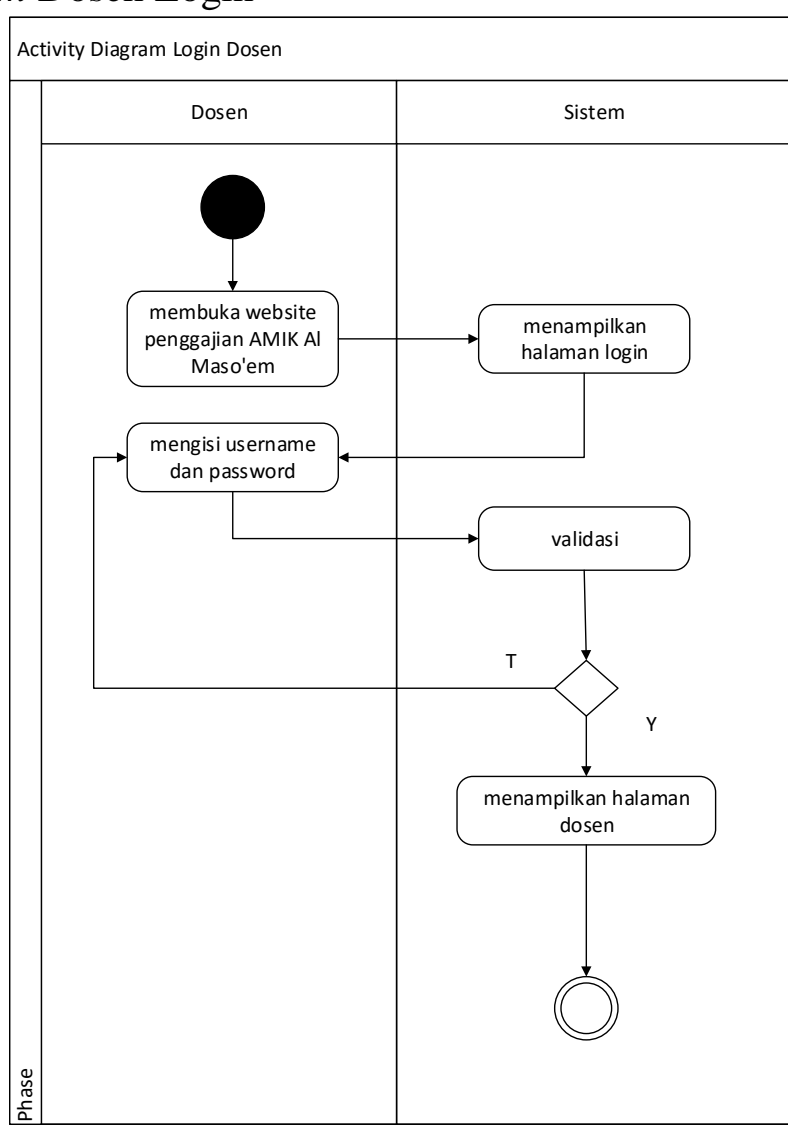

Sumber : Penelitian

Gambar 22 Activity Diagram Dosen Login 
q. Activity Diagram Dosen Lihat Penugasan

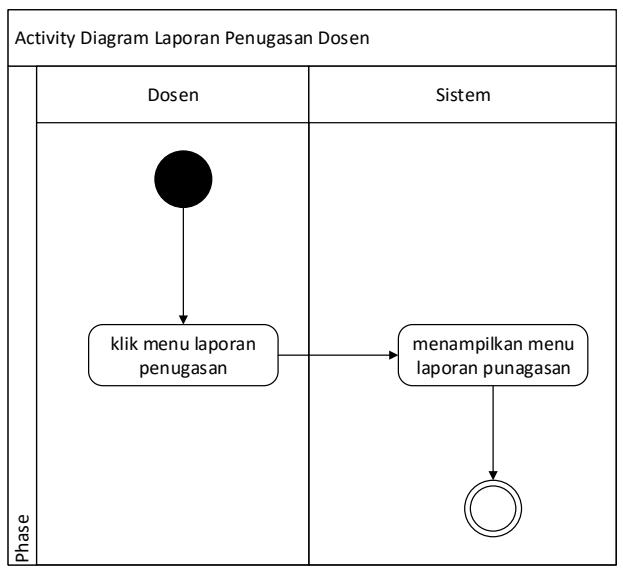

Sumber : Penelitian

Gambar 23 Activity Diagram Dosen Lihat Penugasan

r. Activity Diagram Dosen Slip Gaji

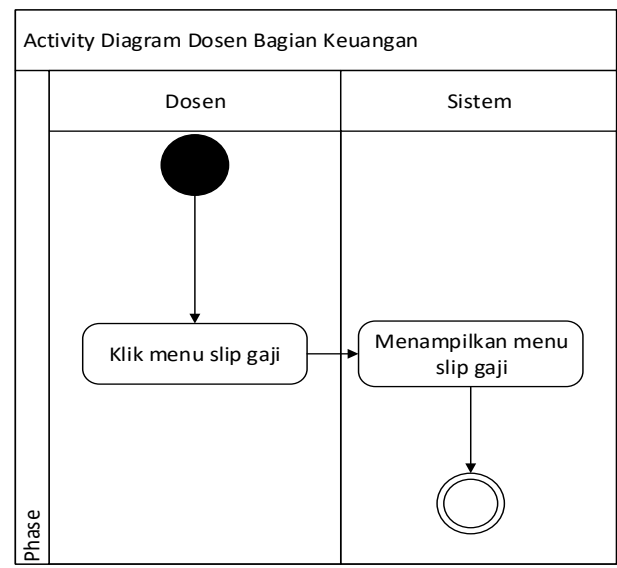

Sumber : Penelitian

Gambar 24Activity Diagram Dosen Slip Gaji

s. Activity Diagram Dosen Logout

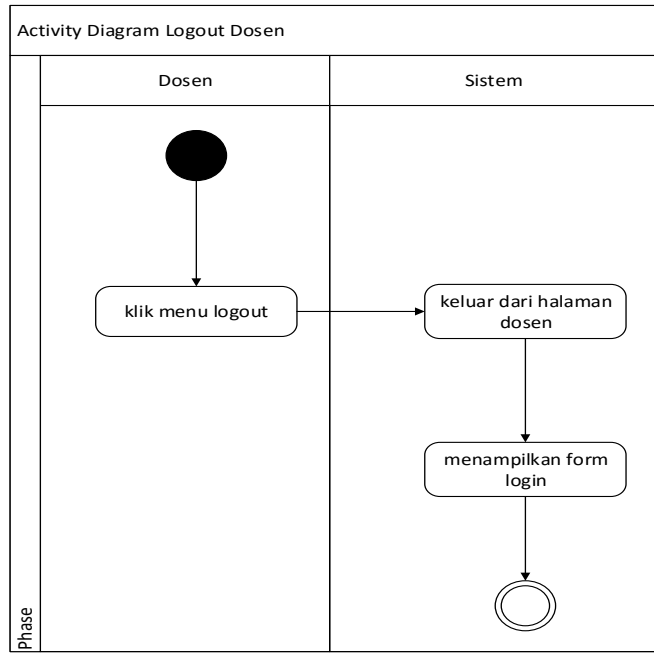

Sumber : Penelitian

Gambar 25 Activity Diagram Dosen Logout

t. Activity DiagramAdmin Dosen 


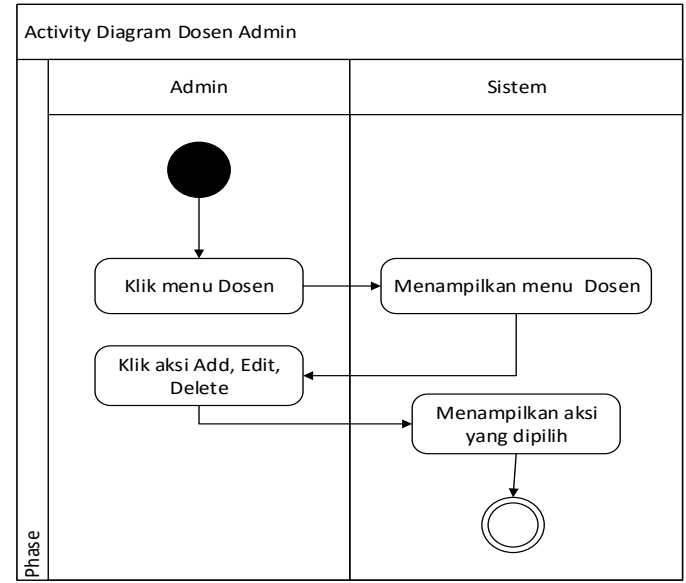

Sumber : Penelitian

Gambar 27Activity Diagram Admin Dosen

u. Activity DiagramAdmin Login

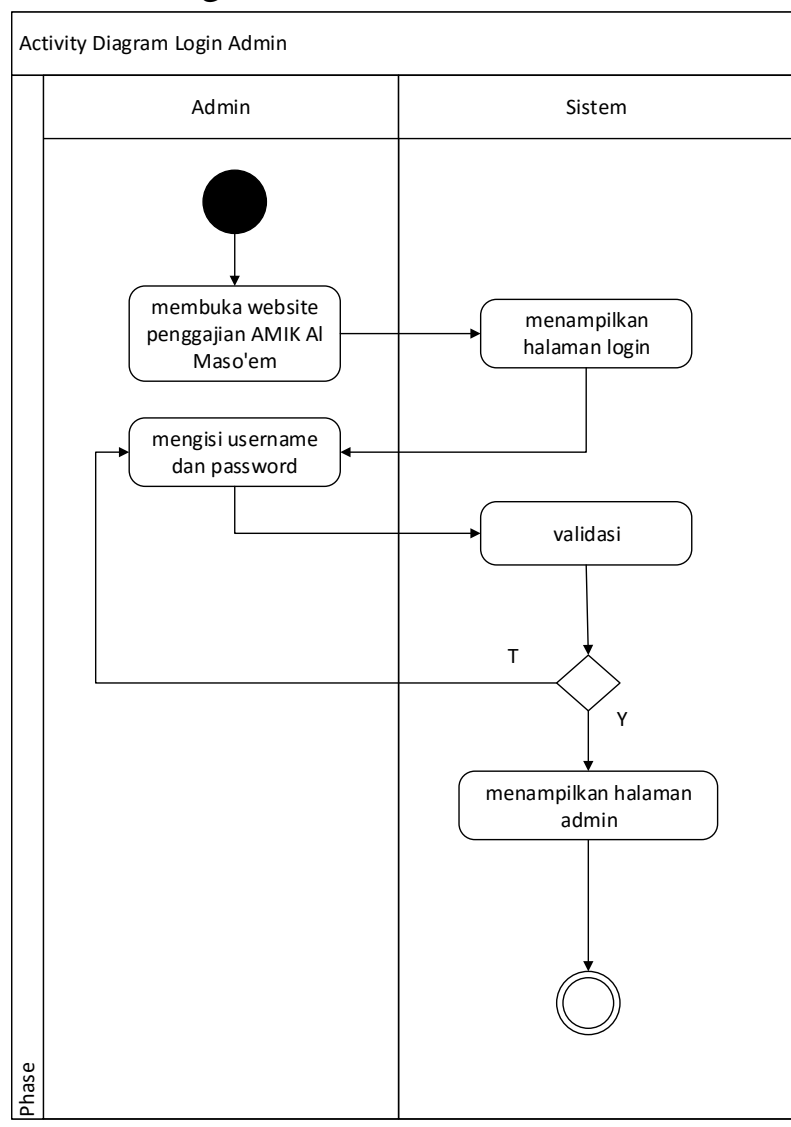

Sumber: Penelitian

Gambar 26Activity Diagram Admin Login

v. Activity DiagramAdmin Level 


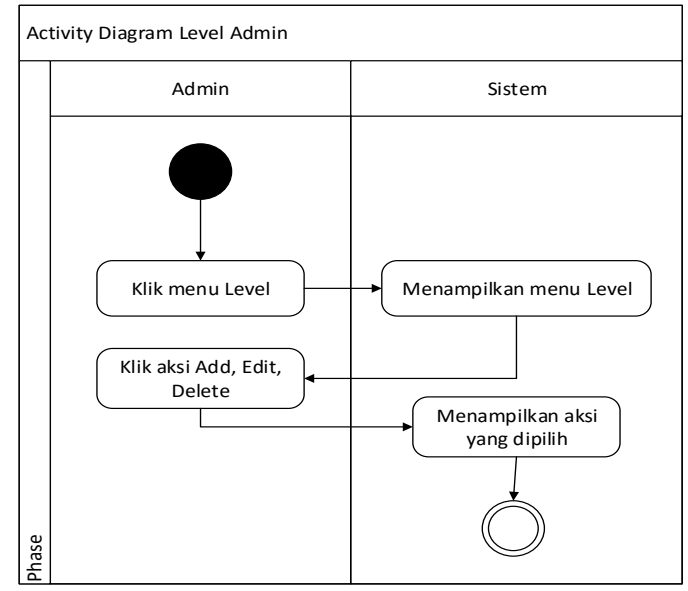

Sumber: Penelitian

Gambar 28 Activity Diagram Admin Level

w. Activity DiagramAdmin Jurusan

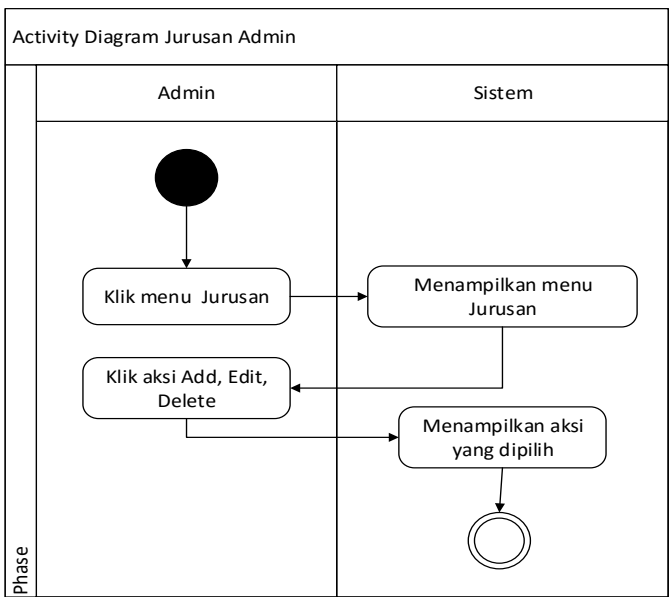

Sumber : Penelitian

Gambar 29Activity Diagram Admin Jurusan

x. Activity Diagram Admin Matakuliah

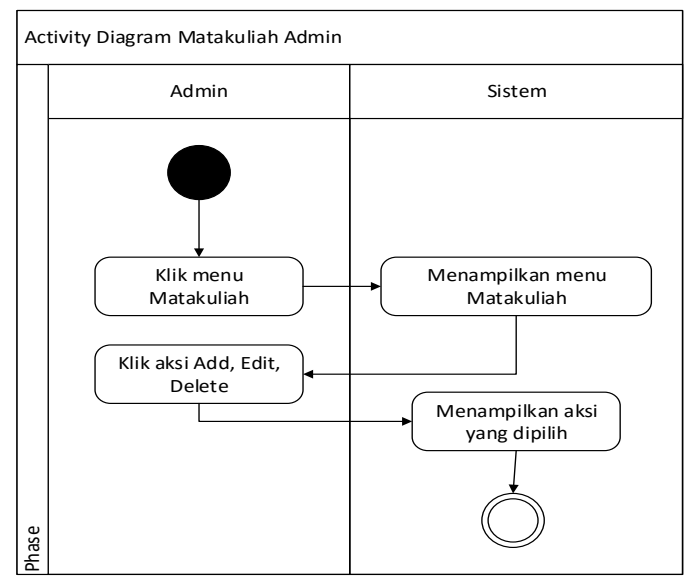

Sumber: Penelitian

Gambar 30Activity Diagram Admin Matakuliah

y. Activity Diagram Admin Potongan 


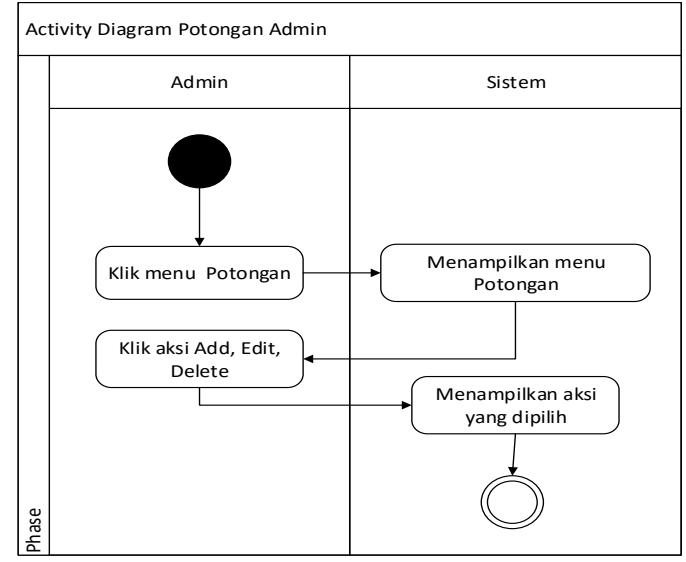

Sumber : Penelitian

Gambar 31 Activity Diagram Admin Potongan

z. Activity Diagram Admin User

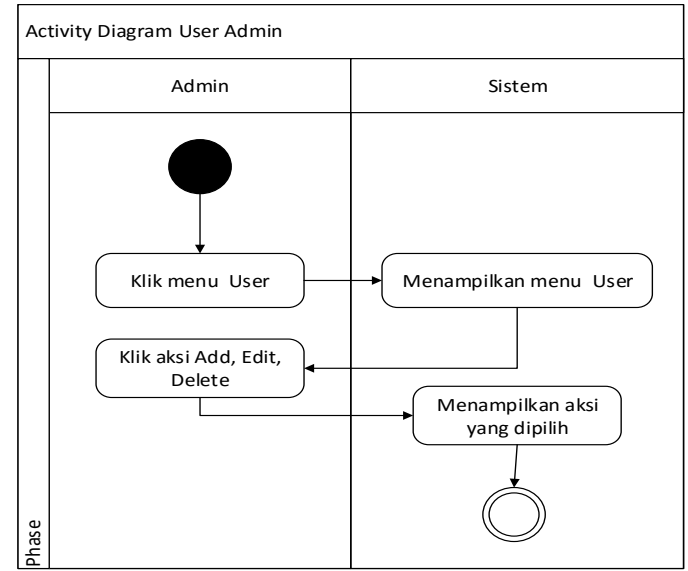

Sumber : Penelitian

Gambar 32 Activity Diagram Admin User

aa. Activity Diagram Admin Penugasan

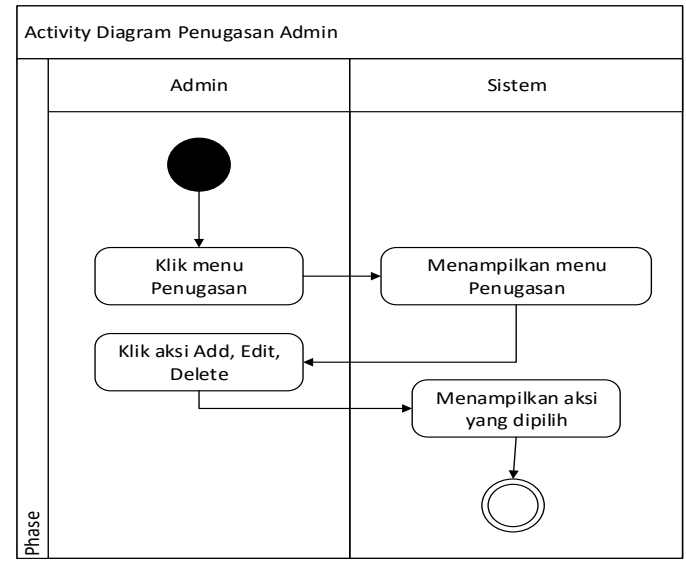

Sumber : Penelitian

Gambar 33 Activity Diagram Admin Penugasan

bb. Activity Diagram Admin Penggajian 


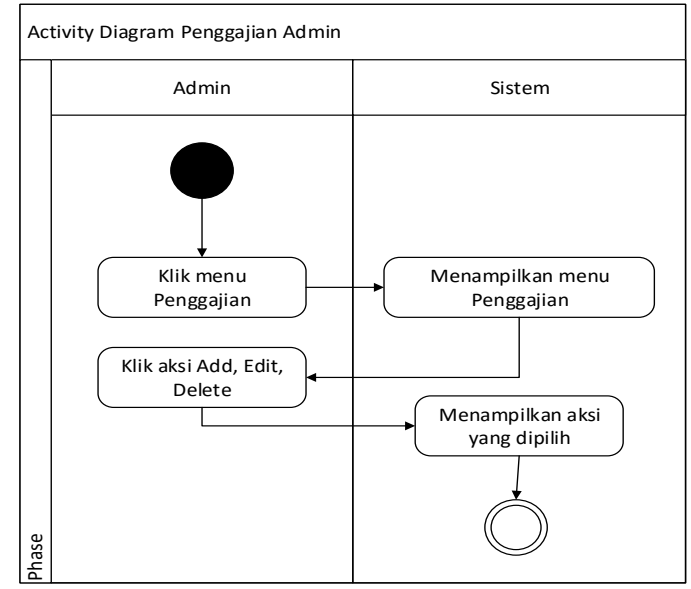

Sumber : Penelitian

Gambar 34 Activity Diagram Admin Penggajian

cc. Activity Diagram Admin Absensi

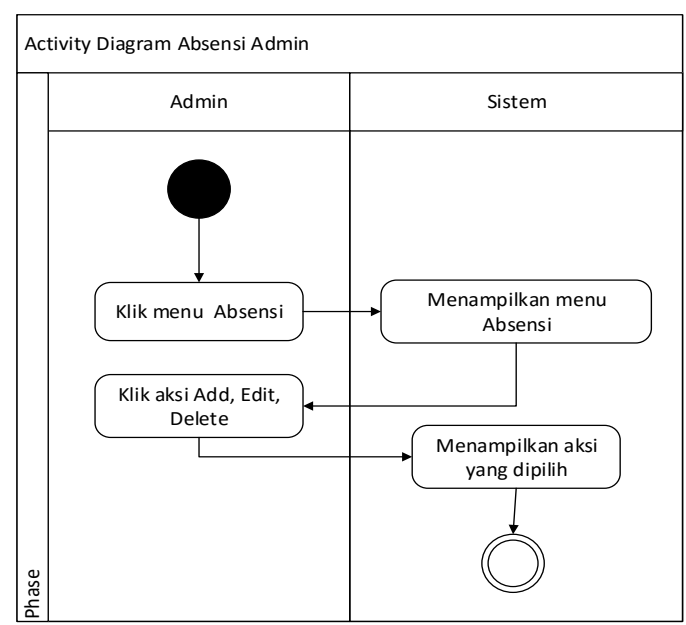

Sumber : Penelitian

Gambar 35 Activity Diagram Admin Absensi

dd. Activity Diagram Admin Laporan Absensi

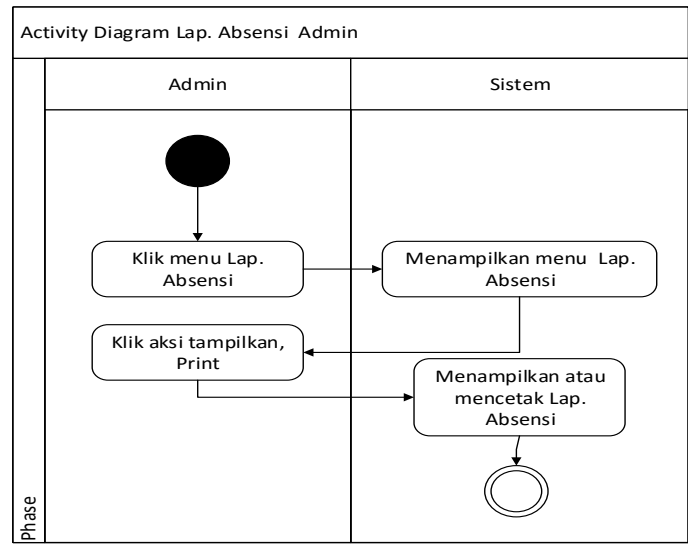

Sumber : Penelitian

Gambar 36 Activity Diagram Admin Laporan Absensi

ee. Activity Diagram Admin Laporan Penugasan 


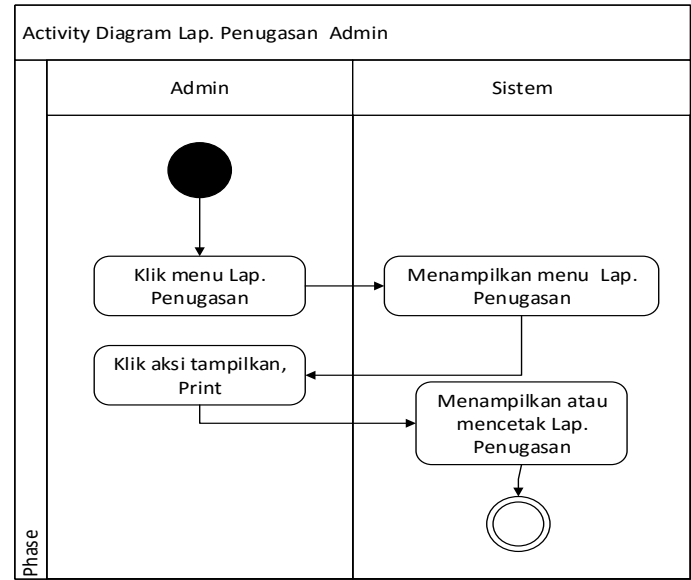

Sumber : Penelitian

Gambar 37 Activity Diagram Admin Laporan Penugasan

ff. Activity Diagram Admin Laporan Penggajian

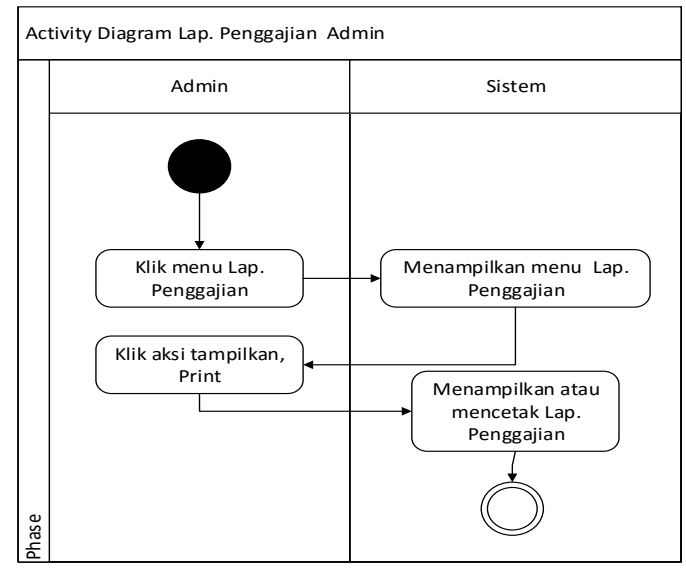

Sumber : Penelitian

Gambar 38 Activity Diagram Admin Laporan Penggajian

gg. Activity Diagram Admin Logout

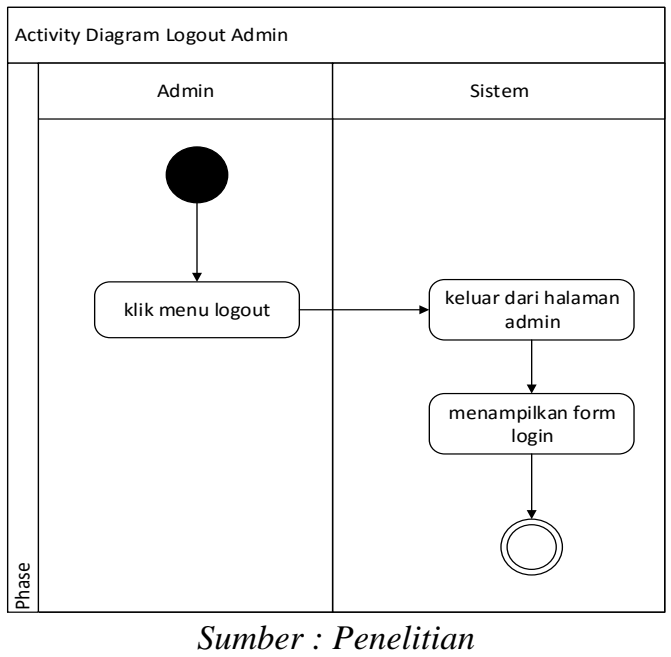

Gambar 39 Activity Diagram Admin Logout

hh. Class Diagram

i) Class Diagram Admin 


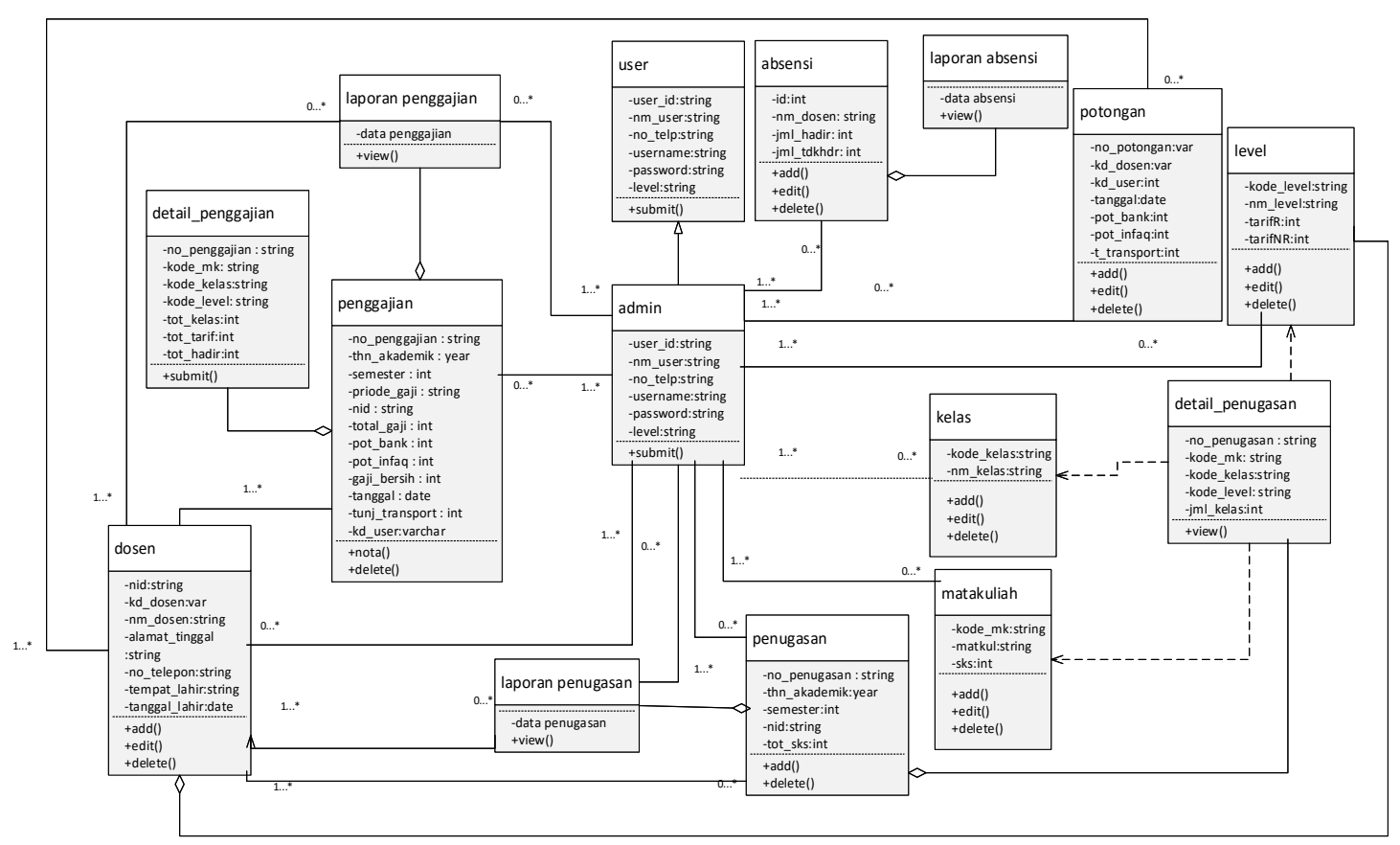

Sumber : Penelitian

Gambar 40Class Diagram Admin

ii) Class Diagram User

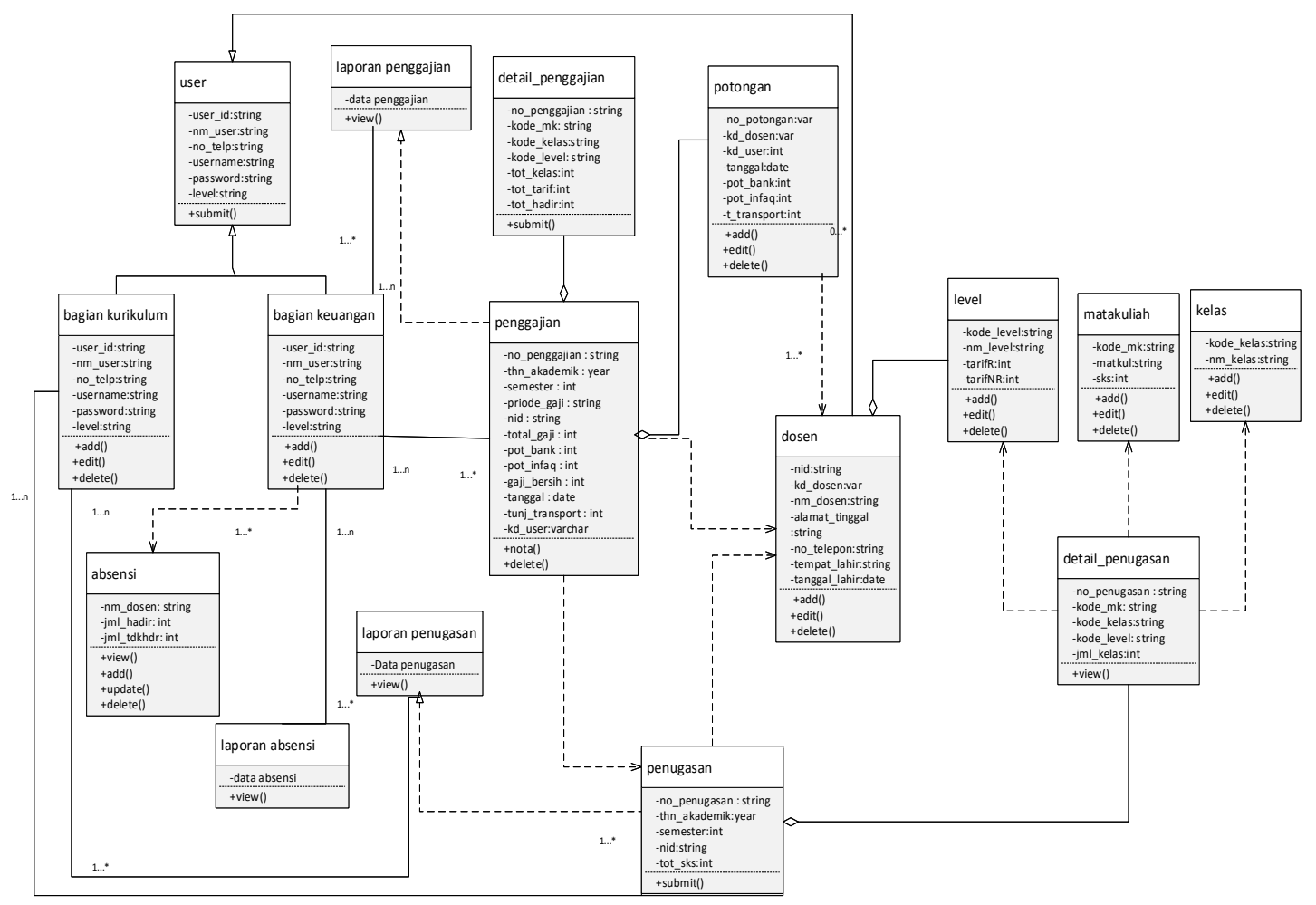

Sumber : Penelitian

Gambar 41Class Diagram User

\section{PENUTUP}

4.1 Kesimpulan 
Berdasarkan uraian sebelumnya maka dapat disimpulkan beberapa hal, yaitu:

1. Data menjadi terintegrasi dalam sebuah database.

2. Mempermudah dan meminimalisir terjadinya duplikasi data dan terhapusnya data.

3. Mempermudah dalam membuat laporan penggajian dosen.

4. Mempermudah dalam pembuatan slip gaji dosen.

\subsection{Saran}

Pembuatan website ini masih belum sempurna dan masih banyak kekurangannya. Oleh karena itu penulis memberikan saran-saran sebagai berikut:

1. Perlunya penyediaan perangkat hardware yang lebih baik dan lengkap dalam kesempurnaan sistem ini.

2. Diharapkan pihak lembaga dapat ikut serta dalam penggunaan sistem penggajian berbasis website ini.

3. Diharapkan pihak lembaga dapat memperhatikan pengembangan website ini secara berkelanjutan.

\section{DAFTAR PUSTAKA}

Fowler, Martin. (2004). UML DISTILLED, 3th Ed,. A Brief Guide to the Standard Object Modeling Language. Yogyakarta : Penerbit ANDI

Gaol, Chr. Jimmy L. (2008). Sistem Informasi Manajemen. Jakarta: Grasindo.

Hartono, Jogiyanto. (2005). Analisis Desain Sistem Informasi :Pendekatan terstuktur teori dan praktik aplikasi bisnis. Yogyakarta: Andi.

Indrajit. (2001). Analisis dan Perancangan Sistem Berorientasi Object. Bandung: Informatika.

Kadir. (2003). Belajar Membuat Website Sederhana. Yogyakarta: Andi offest.

Kroll, Per dan Philippe Kruchten. (2003). The Rational Unified Process Made Easy. Addison Wesley

Ladjamudin, Al Bahra bin. (2005). Analisis dan Desain Sistem Informasi . Tangerang : Graha Ilmu.

Mulyadi. 2013). Sistem Akutansi. Jakarta: Salemba Empat.

Nugroho, Adi. (2009). Rekayasa Perangkat Lunak Menggunakan UML dan JAVA. Yogyakarta: Penerbit Andi

Rahmayani. (2015). Perancangan Sistem Informasi Penggajian Berbasis Website di AMIK Al Ma'soem Bandung. Tugas Akhir Pada Manajemen Informatika AMIK Al Ma'soem Bandung: Tidak diterbitkan. 